\title{
Palustrine Carbonates
}

\section{A.M. Alonso-Zarza ${ }^{1, *}$ and V.P. Wright ${ }^{2}$}

\section{INTRODUCTION}

Palustrine carbonates can be regarded as part of a complex continuum of chemical sediments extending from groundwater calcretes and dolocretes, through tufas and travertines, as well as carbonates formed in discharge wetlands, riparian wetlands, ponds and lakes. These carbonates form by the precipitation of calcium carbonate from groundwaters, surface or groundwater-fed rivers and lakes with a high content of calcium bicarbonate. They are indicators of special hydrological conditions, and the remarkable 
similarities of such carbonates, particularly in the Mesozoic and Cenozoic, is evidence of a recurrent set of environmental factors made all the more intriguing by the apparent lack of a close modern analogue. Palustrine carbonates occur in a variety of aquatic continental settings such as alluvial and fluvial systems, wide lake basins and coastal marine environments. In all cases, the depositional settings are characterised by very low gradients of the lake margin and low energy. Under these conditions, fine-grained carbonates (mainly muds) formed in fresh water commonly contain the remains of charophytes, molluscs and ostracods, and are subjected to subaerial exposure related to fluctuations in water level. Pedogenic processes therefore modify the fine-grained carbonate substrates, giving rise to a variety of palustrine facies and microfabrics, as reviewed by Freytet and Verrecchia (2002). The framework within which these carbonates can be interpreted was clearly envisaged by Freytet $(1965,1971)$, who described palustrine carbonates as the products of the pedogenic modification of non-marine carbonate substrates. According to Freytet (1984, p. 231), a palustrine limestone "must show the characteristics of the primary lacustrine deposit (organisms, sedimentary features) and characteristics due to later transformations (organisms, root traces, desiccation, pedogenic remobilisations)'.

Many palustrine carbonates in the geological record are associated with shallow, hard-water perennial lakes and represent deposition on fluctuating vegetated wetland fringes, as outlined in the classic model of Freytet and Plaziat (1982) based on Late Cretaceous and Early Tertiary successions in southern France. However, many are found along the coastal margins of low-relief carbonate platforms (Martín-Chivelet and Giménez, 1992), within carbonate hinterlands (Armenteros and Daley, 1998), or especially in fluvial settings as discrete carbonate units hosted in siliciclastic formations (e.g., Platt, 1989).

When analysing palustrine deposits, an integrated approach is critical to understanding and accurately interpreting the depositional environment, including examinations of the biota, textures, pedogenic features, the mineralogy and geochemistry of the sediments and the chemistry of the waters from which they formed, as well as the likely geomorphic, hydrological and tectonic settings in which the carbonates accumulated. In addition, the identification of a clear modern analogue is needed in order to understand the processes and the main controls operating in these settings and also to better understand their significance in the fill of continental basins.

Analogues for these sedimentary environments ought to exist today, but anthropogenic activity has probably contributed to the loss of many such settings. The Florida Everglades has been considered a modern analogue for the palustrine fresh-water environments that are known from the sedimentary record (Platt and Wright, 1992), but their specific setting on a low-relief peninsula makes them a relatively unsatisfactory model for fully fresh-water palustrine environments. Alonso-Zarza et al. (2006) proposed 
the Las Tablas de Daimiel wetlands in Spain as a recent analogue for ancient palustrine carbonate environments, because the sedimentary record of this deposit includes most of the distinctive suite of features commonly recognised in palustrine carbonates. In fact, the abundance of palustrine limestones in the sedimentary record has been considered as evidence for the development of ancient hard-water seasonal wetlands in the past (Wright and Platt, 1995). However, more work and detailed studies of recent and modern wetlands are needed in order to better understand the relationship between the sedimentary record of palustrine carbonates and modern environments.

\section{The Sedimentary (Ancient) Record of Palustrine Carbonates}

Palustrine deposits, mostly carbonates, are very common in Mesozoic and Cenozoic continental basins (Figure 1A) (see Gierlowski-Kordesch and Kelts, 2000; Alonso-Zarza and Tanner, 2006), such as the classic examples from the Cretaceous and Tertiary of southern France (Freytet and Plaziat, 1982). Classical palustrine carbonates require the involvement of macrophytes with well-developed root systems, and so are seemingly limited to the post-Silurian. Indeed, their presence in Devonian successions can be used as indicators of the initial occupation of the continents by plants (Dunagan and Driese, 1999).

In many cases, palustrine limestones are difficult to separate from lacustrine ones. Following Freytet (1973), 'true lacustrine limestones' have an entirely subaqueous diagenetic evolution and are either homogeneous or show evidence of reworking and burrowing by animals, whereas 'paludine' limestones result from the emergence of carbonate muds, either in marginal or in more central lake areas. A recent example is Lake Balaton in Hungary, from which Tullner and Cserny (2003) described the oxidation, subaerial erosion or erosion by bottom currents of recently deposited lacustrine sediments. In an extensive review of palustrine and lacustrine facies, Freytet and Verrecchia (2002) considered as lacustrine the following limestones: homogeneous, peloidal, brecciated, gravelly, bioturbated by burrows, bioclastic, algal and stromatolitic plus lacustrine chalk and marl, varves and turbidites. However, peloidal, gravely gravel-grade and brecciated limestones usually show features indicative of their exposure.

\subsection{The primary lacustrine mud}

The description and interpretation of palustrine deposits require an appreciation of how the precursor sediment is modified by subaerial exposure, 

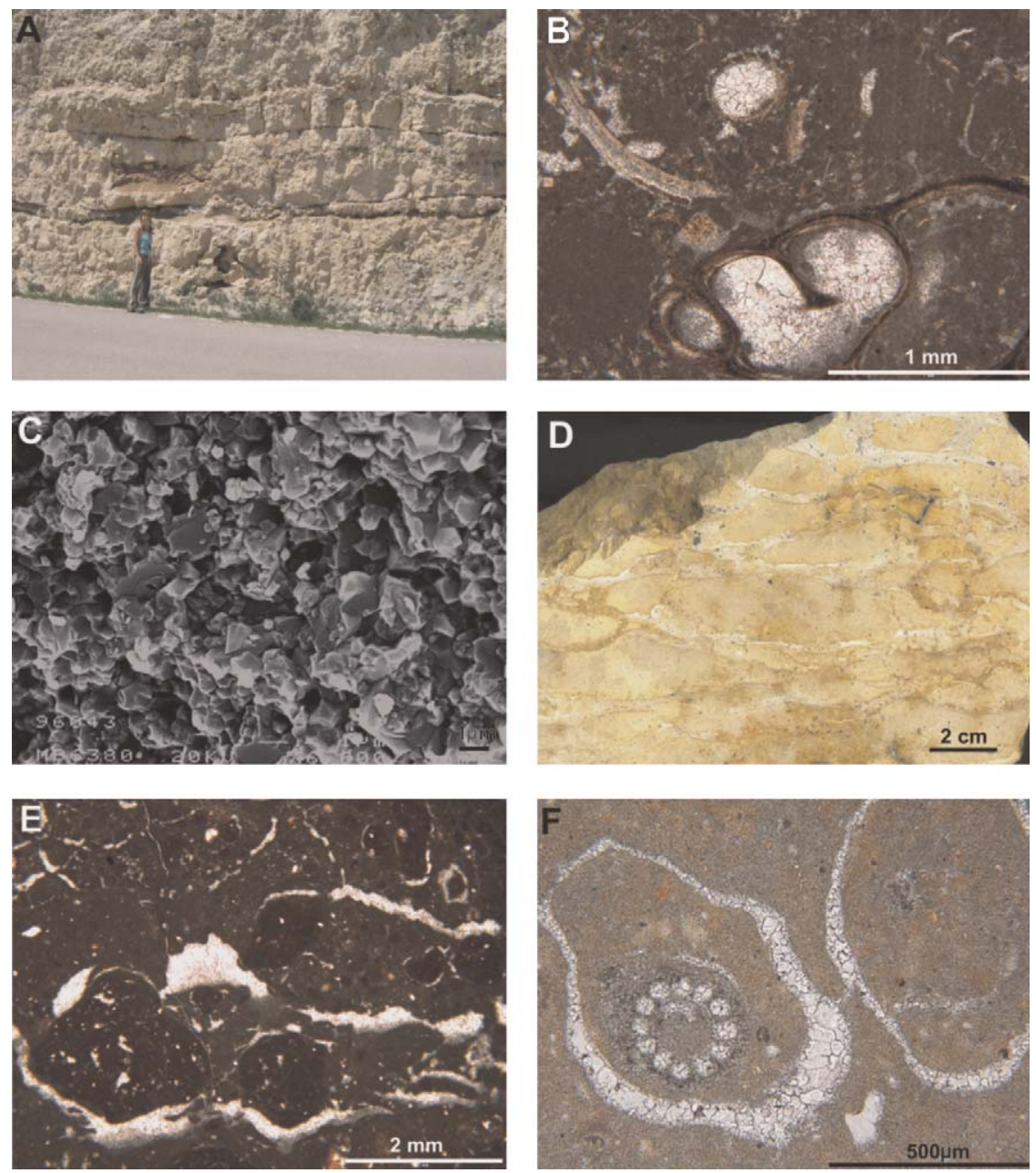

Figure 1 Ancient lacustrine and palustrine facies. (A) Nodular palustrine carbonates showing irregular tops and some interbedded marls. The figure is $1.60 \mathrm{~m}$ high. (B) Lacustrine wackestone with gastropods and charophytes. This is the common aspect of the initial lacustrine muds under microscope. (C) SEM image of the lacustrine mud. The crystals are fine (about $1 \mu \mathrm{m}$ ) and show different morphologies, commonly sub-euhedral. (D) Polished hand sample of a mottled and 'in situ' brecciated limestone with irregular darker haloes. Desiccation cracks are horizontal, following the bedding planes; they are filled by micrite and vadose silt.

(E) Photomicrograph of a mottled limestone showing zones with preferential Fe-staining and planar irregular desiccation cracks, filled by vadose silt and later coarse spar. (F) Photomicrograph of a nodular limestone with circumgranular cracks, which in this case enclose a charophyte stem. 
pedogenesis and diagenesis. In ancient low-gradient and low-energy lakes, the primary carbonate deposit is composed of mud-size sediment, bioclasts (Figure 1B), and other grains such as peloids, coated grains (ooids) or intraclasts. Besides the direct contribution of skeletal (shell) material, much of this carbonate is/was induced by the metabolic activities of microbial biofilms and algae, including charophytes. In recent fresh-water lakes, the mineralogical composition of the primary carbonates is mostly low-magnesian calcite $(<4 \mathrm{~mol} \% \mathrm{Mg})(\mathrm{LMC})$ or high-magnesian calcite ( $>4 \mathrm{~mol} \% \mathrm{Mg})$ (HMC), more rarely aragonite or protodolomite (Tullner and Cserny, 2003). Following diagenesis and mineralogical stabilisation, the mineralogy of the ancient fresh-water carbonates is low-magnesium calcite or dolomite (Wright et al., 1997; Anadón et al., 2000); this affects not only the mud-size carbonate, but also the aragonitic bioclasts, particularly molluscs. Detailed microfabric comparison, based on SEM studies, between ancient and recent carbonate muds shows their striking similarities, both being composed of sub- to euhedral calcite crystals about $1-2 \mu \mathrm{m}$ across (Figure 1C). More rounded crystal morphologies recognised in recent deposits usually show higher amounts of $\mathrm{Mg}$ and are interpreted as high-magnesium calcite or protodolomite (Alonso-Zarza et al., 2006). This agrees with the findings in Lake Balaton. The origin of the carbonate precipitated in the lake is also discussed by Gierlowski-Kordesch (2010 - this volume).

\subsection{Carbonate palustrine facies in the sedimentary record}

Palustrine deposits can be recognised by identifying the features described by Freytet and Verrecchia (2002), including marmorisation, nodulisation and pedogenic recrystallisation, clay authigenesis, desiccation cracks, traces of burrows and roots, and the so-called pseudomicrokarst. Additionally, root moulds, fenestral and alveolar structures, indicating the influence of the vegetation cover, are common in many palustrine limestones. All these features impart on lacustrine deposits a distinctive set of facies described by Alonso-Zarza (2003) and detailed below. Facies 1-6 are probably the more characteristic palustrine facies, but some other facies are closely associated and may give good indications of the general environmental setting within the overall deposystem (facies $7-12$ ).

\subsubsection{Facies 1: mottled limestones}

Facies 1 consists of mottled limestones that are micrites with minor amounts of detrital grains. They show a strong yellow-orange-red mottling (Figure 1D) which, under the microscope, is seen as very diffuse, relatively dark haloes. Charophytes, gastropods, ostracods or any other fossil remains are relatively rare in this facies. The mottled areas may be outlined by desiccation cracks, which show different morphologies such as 
circumgranular, planar or irregular. These cracks are filled by both microsparitic silt and blocky sparry calcite (Figure 1E). It is not uncommon to see evidence of several stages of cementation.

Mottled or marmorised limestones indicate the remobilisation of iron due to changes in the Eh of the groundwater when the water table oscillates (Freytet, 1973). This occurs when the iron content of the sediment is less than $2 \%$. Manganese and calcium can also migrate with iron, enabling the formation of ferruginous nodules, tubular voids, concretions and iron crusts (Freytet and Verrecchia, 2002). Freytet (1973) and Freytet and Plaziat (1982) provided clear descriptions and interpretations of all these features. The mottling is similar to that recognised in poorly drained (gley) palaeosols, as described by PiPujol and Buurman (1997) from the Eocene of the Ebro Basin.

\subsubsection{Facies 2: nodular and brecciated limestones}

The nodular and brecciated limestones consist of centimetre-scale irregular micrite nodules embedded in a softer chalky matrix, or separated by different types of cracks that may remain empty or become filled with microspar and/or sparry calcite. The morphology of the nodules varies from more or less round to angular, forming a breccia. The micrite may contain detrital grains and the debris of charophytes (Figure 1F), ostracods or molluscs. Nodular limestones may be light in colour, but mottling (pseudogley) is also common. The nodulisation process has been explained clearly by Freytet (1973), and is mainly due to desiccation and the subsequent formation of planar to curved fissures that are later filled under vadose and phreatic oxidising conditions.

These limestones can form single, metre-thick beds, indicating that the whole lacustrine succession was subaerially exposed, during a single or multiple events. In other cases only the top or base of lacustrine deposit is nodulised or brecciated, indicating less exposure and the evolution of the lake level. Irregular fenestrae are also present, although not restricted to this facies.

Similar features are most commonly found in intertidal successions where drying and wetting cycles are frequent. Their presence in some palustrine successions is evidence of short periods of exposure and rewetting along shorelines or in wetlands.

\subsubsection{Facies 3: limestones with vertical root cavities}

These are matrix-rich limestones with gastropod shells, charophytes, ostracods, desiccation cracks, and fenestral and alveolar structures (Figure 2A). Root cavities are large, irregular, vertical cavities several centimetres wide and with lengths up to decimetre scale. They are commonly wider at the top of the beds and taper downwards. These cavities may be empty or partially filled 
with a looser micrite matrix, microspar peloids, intraclasts, bioclasts and spar cement. Limestones with vertical root cavities either occur as tabular beds or display a wavy, convex-up upper surface (Figure 1A). Another characteristic of this facies is that it is commonly more indurated than any other palustrine or lacustrine deposits, and is therefore very prominent at outcrop scale.

Limestones with vertical root cavities commonly display a columnar structure. The vertically elongate columns can be up to $10 \mathrm{~cm}$ in diameter and may reach $1 \mathrm{~m}$ in length; horizontal cracks are a common feature. The columns are thought to form by calcification around vertically penetrating roots. Similar to the prismatic structures recognised in calcretes (Esteban and Klappa, 1983), these columns may be found in either clayey or softer carbonate sediments. Roots and associated micro-organisms can also brecciate and nodulise the host carbonate mud in areas of rhizosphere influence. This effect is especially visible in marly sediments.

\subsubsection{Facies 4: pseudomicrokarst}

Facies 4 consists of limestones with pseudomicrokarst. Plaziat and Freytet (1978) introduced this term to describe limestones with irregular and complex cavities that resemble a karst system in which the cavities are small, mostly cylindrical, and vertically elongated. Individual cavities are only a few centimetres long, but are associated with larger networks on the decimetre scale. The prefix 'pseudo' is used because the enlargement of the cavities is mostly mechanical (root activity and desiccation); dissolution is only a minor process. The cavities show sharp boundaries and are commonly very irregular in form (Figure 2B). However, in some cases, the margins are rounded, indicating that some dissolution has also occurred (Platt, 1989).

The pseudomicrokarst networks appear to have developed from vertical root cavities which have become connected to each other horizontally; this is especially so at the top of the beds. Desiccation cracks are common and arranged in an orthogonal network; they may cut root cavities. Cavity fills are complex and include peloids, coated grains and intraclasts (see below) as well as different types of cements from vadose to coarse blocky spar (Figure 2C). The succession of these cements is a criterion for deciphering the movements of the water table (Freytet and Plaziat, 1982).

\subsubsection{Facies 5: peloidal, coated grain and/or intraclastic limestones} Peloidal, coated grain and/or intraclastic limestones are important components of palustrine limestones. Peloids are more or less rounded grains formed by micrite including some clay, pseudospar or compound micritic grains, and may be up to several millimetres in diameter (Figure 2D). They are commonly coated with irregular laminae formed of dark micrite alternating with lighter micrite layers that may include smaller peloids. SEM 

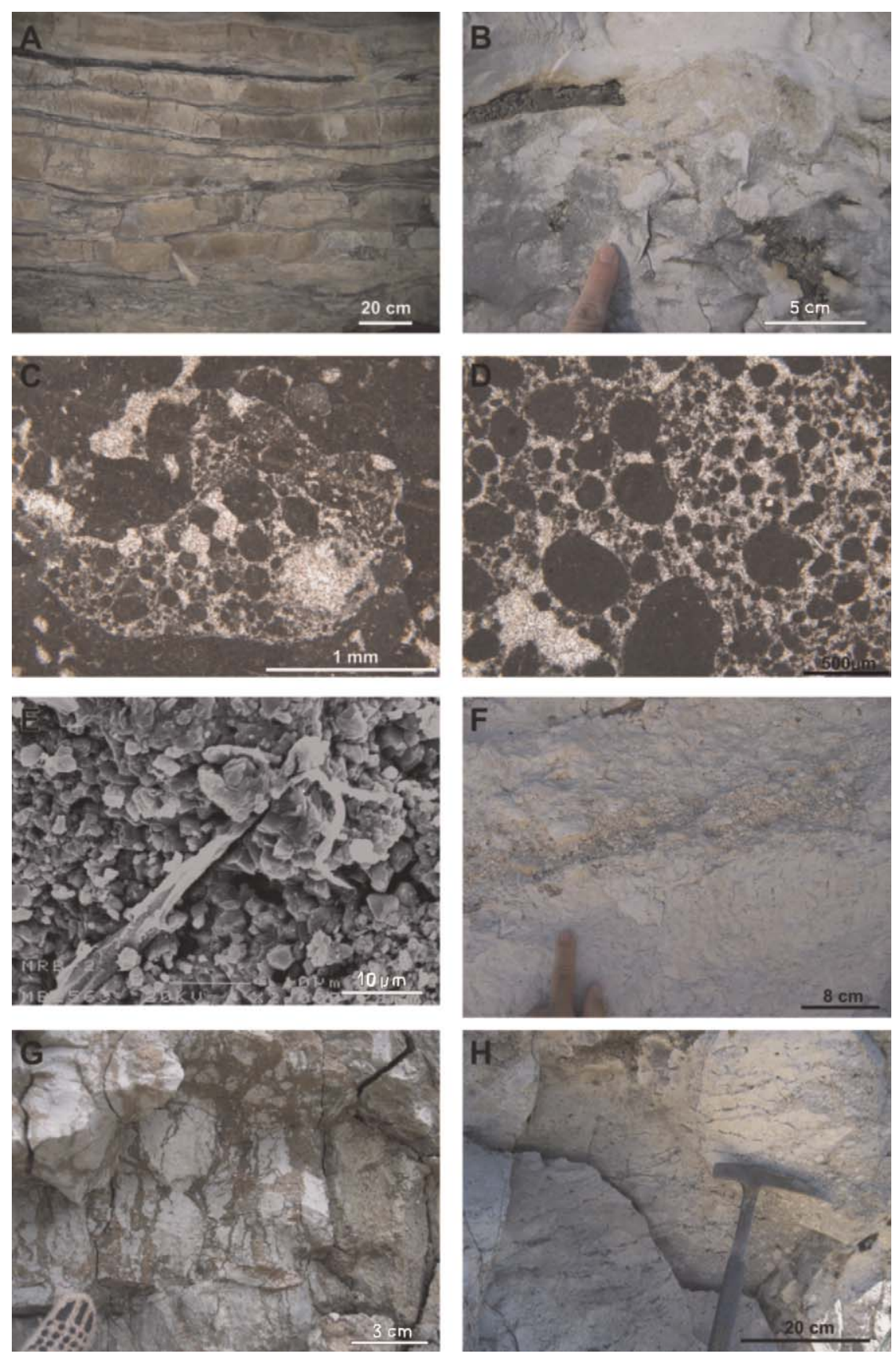
observation of the latter (Alonso-Zarza et al., 1992) reveals that a network of fungal filaments arranged within micrite crystals forms the coatings.

Intraclasts are more varied in size, ranging from less than a millimetre to several centimetres long; they are rounded to angular and are commonly poorly sorted. The intraclasts consist of micrite with scarce fossil debris. Root moulds, alveolar septal structures (Wright, 1986), organic filaments (Figure 2E) and different types of desiccation cracks are easily recognised within the intraclasts as well as in the intragranular pores. The peloidal, coated grains and intraclastic sediments are commonly cemented by calcite mosaics, the sizes of which vary between that of microspar and coarsely crystalline. These sediments occur in different types of cavities and form a complex network. This facies has also been named granular limestones and may form through the process of grainification (Mazzullo and Birdwell, 1989; Wright, 1990), which also occurs in peritidal settings. These appear as beds formed entirely of this facies at the top or base of lacustrine and peritidal deposits, or filling different types of cavities. A characteristic is that both the grains themselves and the cavities and surrounding matrices show clear evidence of multiple phases of fragmentation (grainification), coating, internal sediment, deposition of microsparitic silt and blocky calcite cementation. A common feature of these cavity fills is inverse grading.

\subsubsection{Facies 6: Laminar calcretes}

Laminar calcretes are a common feature and consist of centimetre-thick sheet-like or stomatolitic, very irregularly laminated micrites. Some forms are densely laminated but others are fenestral. The former are similar to crusts associated with calcrete profiles (see Alonso-Zarza and Wright, 2010 - this volume), but the latter are calcified root mats (Wright et al., 1988). In all cases the micromorphology shows a wide range of biogenic structures such as calcified organic filaments, alveolar septal structures,

Figure 2 Ancient palustrine facies. (A) Decimetre-thick beds of palustrine carbonates, the tops of which contain vertical roots. (B) Top-most part of a palustrine bed with highly irregular pseudomicrokarst filled by micritic clasts. The cavities are very irregular. (C) Photomicrograph of a pseudomicrokarst infill consisting of micritic grains embedded in calcite cement. (D) Peloidal limestone. The peloids are more or less rounded and show poor sorting. In this case, they do not show micritic coatings. (E) SEM view of the peloidal limestones. The micrite crystals are very fine. Organic filaments, contributing to the breaking of the micrite, are visible. (F) Conglomerates consisting of limestone clasts derived from the lower palustrine limestones with desiccation and root traces (above finger). (G) Green marlstone beds with various types of desiccation and root cracks resulting from in situ brecchiation of the bed; intraclasts are visible. (H) Palustrine sepiolite bed, showing the same features as the palustrine carbonates, such as desiccation, formation of intraclasts and some reworking. In this case, the bed is silicified. 
needle fibre calcite and peloids, amongst many others (Alonso-Zarza and Wright, 2010). In certain settings, root mats formed at the water table can become calcified (Mount and Cohen, 1984), and the common occurrence of such features in palustrine successions is evidence for near-surface water tables around the lake margins and in wetlands.

\subsubsection{Facies 7: organic-rich marlstone and clays}

Facies 7 consists of organic-rich marlstone and clays that are typically massive to poorly laminated and that include varied amounts of fragmented gastropod shells, plant remains, locally some carbonate nodules, and carbonate and clay intraclasts. Commonly, these deposits are very rich in micro-mammal remains, so they can provide useful chronostratigraphic data, such as in the Teruel Graben (Alonso-Zarza and Calvo, 2000). These marlstones and clays occur interbedded with clastic deposits or between lacustrine/palustrine carbonates, showing sharp or transitional boundaries.

\subsubsection{Facies 8: carbonate-filled channels}

The carbonate-filled channels that constitute facies 8 are irregularly bedded with lower erosive surfaces and upper, commonly planar ones with root traces (and so may show prismatic structures). The channel fill consists of oncoids, bioclasts, phytoclasts and reworked micritic grains (Figure 2F). Channels are often in close association with organic-rich marlstones into which they have eroded. In some cases, these channel fills likely indicate longer periods of desiccation of the lacustrine sediments and subsequent reworking by incision of fluvial channels that eroded the desiccated carbonate palustrine deposits.

\subsubsection{Facies 9: green to brown marlstones}

Facies 9 is built by green to brown marlstones which are usually massive to slightly laminated. They include some micritic carbonate nodules, millimetres in diameter, and cylindrical root tubes preserved in carbonate. They may be interbedded with any other deposits, either clastics or carbonates. They contain root traces and desiccation cracks, which contribute to their brecciation (Figure 2G). Changes in colour are indicative of the evolution of the ground and surficial waters. Occasionally, small silt-ripple beds are interbedded within them. These marls represent the ponded areas of the distal fan close to the lake margins or the wet mudflat deposits of a wider lake environment; in either case they represent marsh areas with an extensive vegetation cover and a high groundwater table. 


\subsubsection{Facies 10: travertines}

Travertines may form either in spring orifices or in spring-marginal pools (Szulc et al., 2006), from discharging groundwater at elevated temperatures ('thermal' waters). Travertines from both settings are very rich in calcified algae and reed-like, vascular plants and may include calcitic rafts. Marginal pool deposits include finely laminated peloidal limestones which are absent in the spring orifices. The encrustations are due to calcification driven by epiphytic microbial colonies covering the vascular plants. In the Upper Triassic of southern Poland, the presence of travertines in palustrine environments indicates that the source of water was a former hydrothermal karst area. In the Aguilar Formation (Northern Spain), the occurrence of travertines intercalated between lacustrine/palustrine deposits is controlled by an active fault line which favoured the discharge of water into the system (Hernández et al., 1998).

\subsubsection{Facies 11: tufa deposits}

Tufa deposits are calcareous fresh-water deposits resulting from calciumcarbonate precipitation from waters at ambient temperature; they contain the remains of micro- and macrophytes, invertebrate and bacteria (Ford and Pedley, 1996). Tufa deposits are common in fluvial/palustrine/lacustrine systems such as the Miocene of the Ebro Basin (Vázquez-Urbez et al., 2002) and the Palaeogene of Mallorca (Arenas et al., 2007), for which different sedimentary models have been proposed. However, the exposure features, such as desiccation cracks or root-related features, are difficult to see in the tufa facies, probably because of the large grain size of the deposits. The facies typically includes boundstones, rudstones and packstones with bryophytes, stems, phytoclasts and oncolite rudstones, amongst many other components (Arenas et al., 2007).

\subsubsection{Facies 12: other non-carbonate palustrine deposits}

All other non-carbonate palustrine deposits jointly are included in facies 12 . They are common in the sedimentary record and constitute the major par of a suite of evaporites, and dolomites and clays, including dolomitic muds with subaerial exposure features (Calvo et al., 1995), and bioturbated sulphates, mostly lenticular gypsum with a number of modifications by plants and animals, formed in marginal lacustrine areas (Rodríguez-Aranda and Calvo, 1998). Of special interest are Mg-rich clays as sepiolite and palygorskite, which may show exactly the same features as palustrine carbonates, such as brecciation and nodulisation (Figure $2 \mathrm{H}$ ). These special clays can include sepiolite that was precipitated directly in ponds and that was pedogenically modified later (Bustillo and Alonso-Zarza, 2007). 


\subsection{Genetic aspects of the palustrine carbonate facies}

The facies described above clearly show the different intensities with which fine-grained subaqueously formed continental carbonates are affected by pedogenesis and reworking. The variability of the processes involved in each palustrine microenvironment (Figure 3) can be related to the proportion of time spent subaerially exposed (referred to as the 'exposure index') (Platt and Wright, 1992). A continuum from less pedogenically modified limestones to those that are totally modified can be identified, taking into account mostly the palustrine facies ( 1 to 5 ) described above (facies $4-8$ of Figure 3 ). This continuum reflects not only the degree of pedogenic modification but also the relative influence of physicochemical versus biogenic processes.

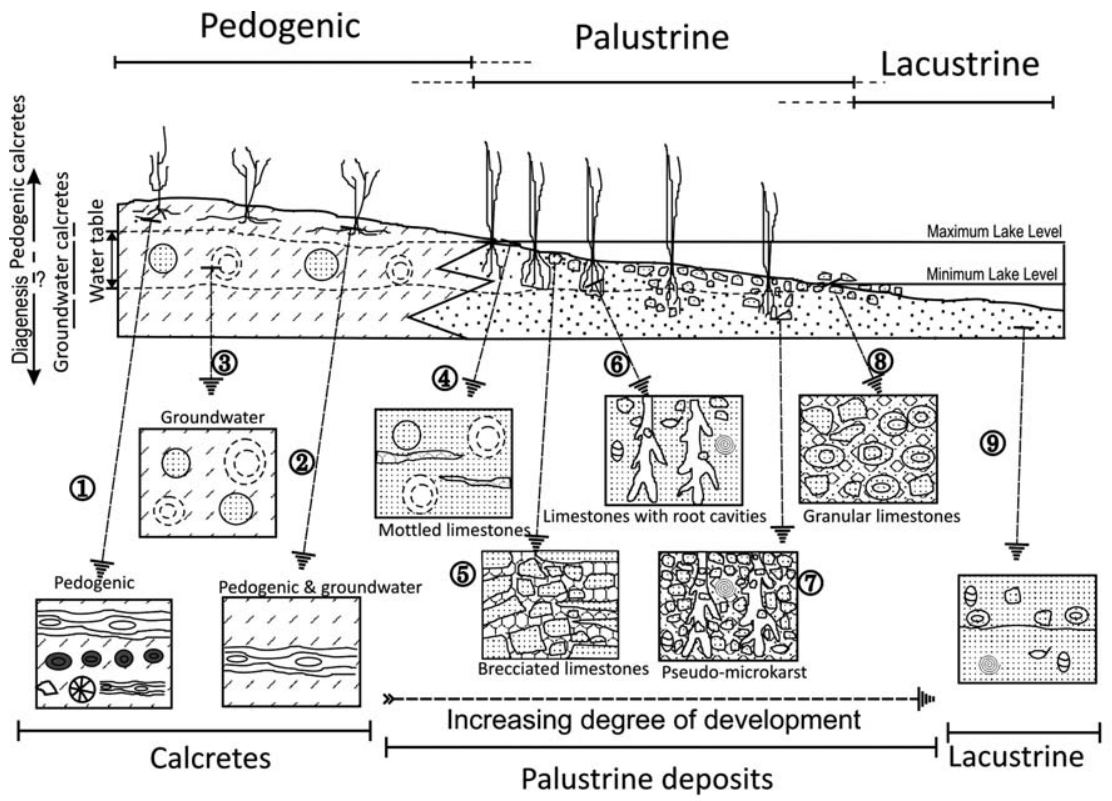

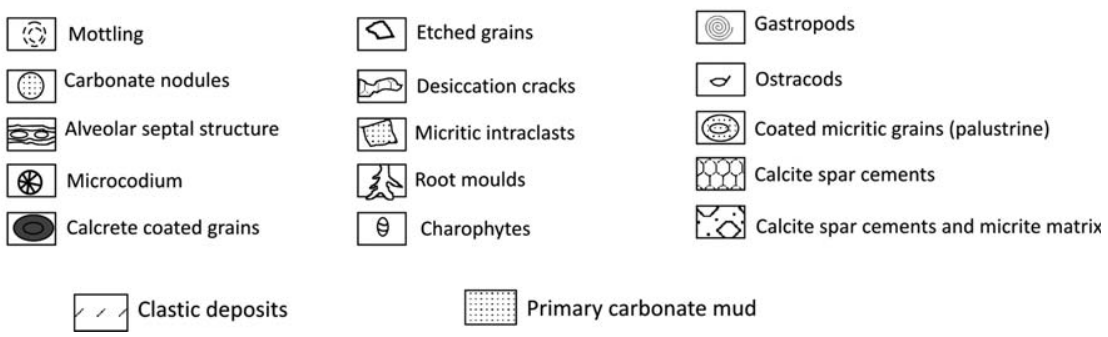

Figure 3 The various palustrine-calcrete facies associations. Common petrographic aspects of these carbonates are also shown. From Alonso-Zarza (2003). 1-3: Calcretes; 4-8 (1-5 in the text): different palustrine deposits from the less (4) to the more developed ones (8); 9: non-pedogenically modified lacustrine deposits. 
Mottled and nodular limestones mostly reveal the influence of physicochemical processes such as desiccation and iron mobilisation; both limestone types may be considered as less developed palustrine limestones. Limestones with root cavities, as well as those with a prismatic structure, indicate the presence of a well-established vegetation cover. Roots act in two different ways: (1) by penetrating the carbonate muds and/or (2) inducing biochemical precipitation of carbonate around the rhizosphere. In either case, the carbonates formed under these conditions indicate more intense soil modification and longer intervals of exposure.

The more developed palustrine limestones are the granular limestones (peloidal or intraclastic) and those carbonates with pseudomicrokarst. In both, the result is an important loss of the primary muddy texture of the deposits. These processes of formation of syngenetic grainstones, or to use a wider term, granular limestones, have been extensively described not only from palustrine environments (Freytet and Plaziat, 1982; Alonso-Zarza et al., 1992; Armenteros et al., 1997), but also from peritidal settings (Mazzullo and Birdwell, 1989). The formation of these textures is driven by the repeated wetting and drying of the carbonate mud and by root systems that penetrated the recently deposited mud to reach the water table. This, together with the desiccation of the surface of the sediment, contributes to intense fragmentation of the mud. The intensity and duration of these processes, as well as any later rise in the water table during wetter periods, can cause the reworking, concentration and coating of the mud fragments. Movement of grains over the sediment surface gives rise to the formation of beds of mostly (but not necessarily) coated micrite grains that accumulate at some distance from the place where the fragmentation originally occurred.

In contrast, pseudomicrokarst and brecciated limestones are formed 'in situ'. In both cases, the activity of micro-organisms such as fungi and bacteria plays a significant role, especially in the coating of some grains (Alonso-Zarza et al., 1992).

\section{Wetlands: The Recent Analogues for Ancient PALUSTRINE ENVIRONMENTS?}

The search for a recent sedimentary environment where the deposits show similar features and composition as do ancient palustrine carbonates has been the aim of many studies during the last 15 years. Narrowing palustrine deposits to a specific setting is difficult because they occur in a broad spectrum of depositional environments including: (1) coastal plains, such as the Florida Everglades (Platt and Wright, 1992), and the Lower Cretaceous of Croatia (Dini et al., 1998), (2) alluvial settings, with examples from the Upper Jurassic Western Interior, USA (Dunagan and Turner, 2004), the Tertiary of Wyoming (Bowen and Bloch, 2002) and the 
Miocene of Spain (Armenteros and Huerta, 2006) and (3) marginal areas of larger ancient (Freytet and Plaziat, 1982) and recent lacustrine systems, as the previously mentioned Lake Balaton in Hungary (Tullner and Cserny, 2003).

It seems to be in common agreement that wetlands constitute the closest recent analogue to the ancient environment in which palustrine deposits accumulated; in fact, Wright and Platt (1995) noted that the abundance of ancient palustrine carbonates is a testimony to the widespread development of seasonal wetlands in the past, which is consistent with the widespread occurrence today of wetlands, covering some $6 \%$ of the land surface (Marty and Meyer, 2006). They have been recognised in all climatic zones and on all continents except Antarctica (Mitsch and Gosselink, 1993). The variability of modern wetlands makes it difficult to establish an all-encompassing sedimentary definition because there are a number of ecological, hydrological and sedimentary parameters that should be considered.

Following the definition by Cowardin et al. (1979), palustrine wetlands must fulfil one or more of the following requirements: the land supports predominantly hydrophytes, at least periodically; the substrate is predominantly undrained hydric soil, and the substrate is non-soil and is saturated with a water cover or covered by shallow water at some time during the growing season. Moreover, there are some specific requirements for water depth and composition, that is, less than $2 \mathrm{~m}$ deep at low water, and salinity from ocean-derived salts of less than $0.5 \mathrm{ppt}$. Additionally, there is a lack of wave-formed features on the shorelines (Cowardin et al., 1979). More recently, wetlands have been defined as landscape units with a spatially and temporally positive hydrologic anomaly in relation to the adjacent drier land without being rivers, lakes or marine environments (DGOH, 1991).

The study of the sediments recently deposited in wetlands, especially if they are carbonates, is crucial to determine if modern wetlands constitute the most likely analogue for palustrine carbonate successions. In recent years, the use of different technologies to core lake systems has contributed to a better understanding of these sediments; most of the work, however, is focused on siliciclastics, such as the Loobi Swamp in Kenya (Ashley et al., 2004). Some detailed studies of carbonate deposits in marginal areas of lakes are being carried on in Lake Balaton (Tullner and Cserny, 2003). Apart from the lack of studies on recent carbonate wetlands (or even lakes), one additional problem is diagenesis, which may transform the mineralogy and texture of the initial sediments to make them more stable and lithified.

The Las Tablas wetlands are located in the southern Meseta of Spain and were formed initially by the flooding of the Guadiana and Giguiela rivers, together with the upwelling of groundwater through many springs. The relative contribution of surface waters versus groundwater varies in space and time. The total wetland area was about $60 \mathrm{~km}^{2} 30$ years ago, but today 
it is only of $16.75 \mathrm{~km}^{2}$, because of increased water usage by Man. The Las Tablas wetlands are shallow, usually less than $1 \mathrm{~m}$ deep (Figure 4A and B). The aquatic environment is highly turbid, with high sedimentation rates. The dominant anions are carbonate and sulphate. The climate is classified as cold, temperate continental with a dry season. Isotherms range from 12 to $14^{\circ} \mathrm{C}$, rainfall is from 400 to $500 \mathrm{~mm}$ year $^{-1}$, and potential evaporation averages $778 \mathrm{mmyear}^{-1}$. All these data are extensively discussed in Álvarez-Cobelas and Cirujano (1996) and Dorado-Valiño et al. (2002). The Las Tablas wetlands are now a National Park under a strong preservation policy.

The core of the Las Tablas de Daimiel wetlands shows a 38.5-m thick succession of sediments that range from the Middle Pleistocene (even Early?) to the Holocene. The study of the core (Alonso-Zarza et al., 2006) has shown that the more indurated sediments exhibit clear palustrine features all through the core, but specially in the upper Holocene part, where the sediments consist mostly of low-Mg calcite (45-100\%), with varying amounts of quartz $(0-35 \%)$, clays $(0-20 \%)$ and aragonite from shells $(0-5 \%)$. In this part, no traces can be found of dolomite, opal, high$\mathrm{Mg}$ calcite or organic matter, which occur in the Middle Pleistocene part. Three main carbonate facies have been recognised: (1) massive chalky carbonates; (2) indurated wackestones to packstones with gastropods, oncoids, ostracods and charophytes (Figure 4C), at some intervals showing desiccation cracks, alveolar septal structures, pseudomicrokarst and mottling; and (3) packstones of intraclasts containing some quartz grains (Figure 4D). The massive chalky carbonates represent deposits that have not been modified by pedogenesis. The indurated limestones formed in the shallower areas, as indicated not only by the sedimentary features but also by the low aquatic pollen diversity and the emergent pollen taxa recorded in the sediments (Valdeolmillos Rodríguez, 2005). In this environment, the sediments were intensively modified, allowing the micrite crystals to change their size (larger crystals) and shape (Figure 4E). In addition, phreatic and vadose cementation also contributed to the lithification of the sediments. Packstones of intraclasts in Las Tablas have been interpreted as the result of desiccation and reworking events of the slightly lithified wackestones, and reflect more humid periods that caused the rise of the lake water. Some of the carbonate deposits show calcified microbial tubes similar to those recognised in calcretes (Figure 4F). Apart from the carbonate deposits, peat beds are also common. The stableisotope data of the carbonates are also very similar to those recorded in other palustrine deposits (Arenas et al., 1997; Alonso-Zarza and Calvo, 2000; Tandon and Andrews, 2001; Dunagan and Turner, 2004), with a lack of covariance of $\mathrm{C}$ and $\mathrm{O}$ stable isotopes indicating an open system. With all these data in mind, it is likely that this wetland area can be considered as the best modern analogue for ancient palustrine carbonates. 

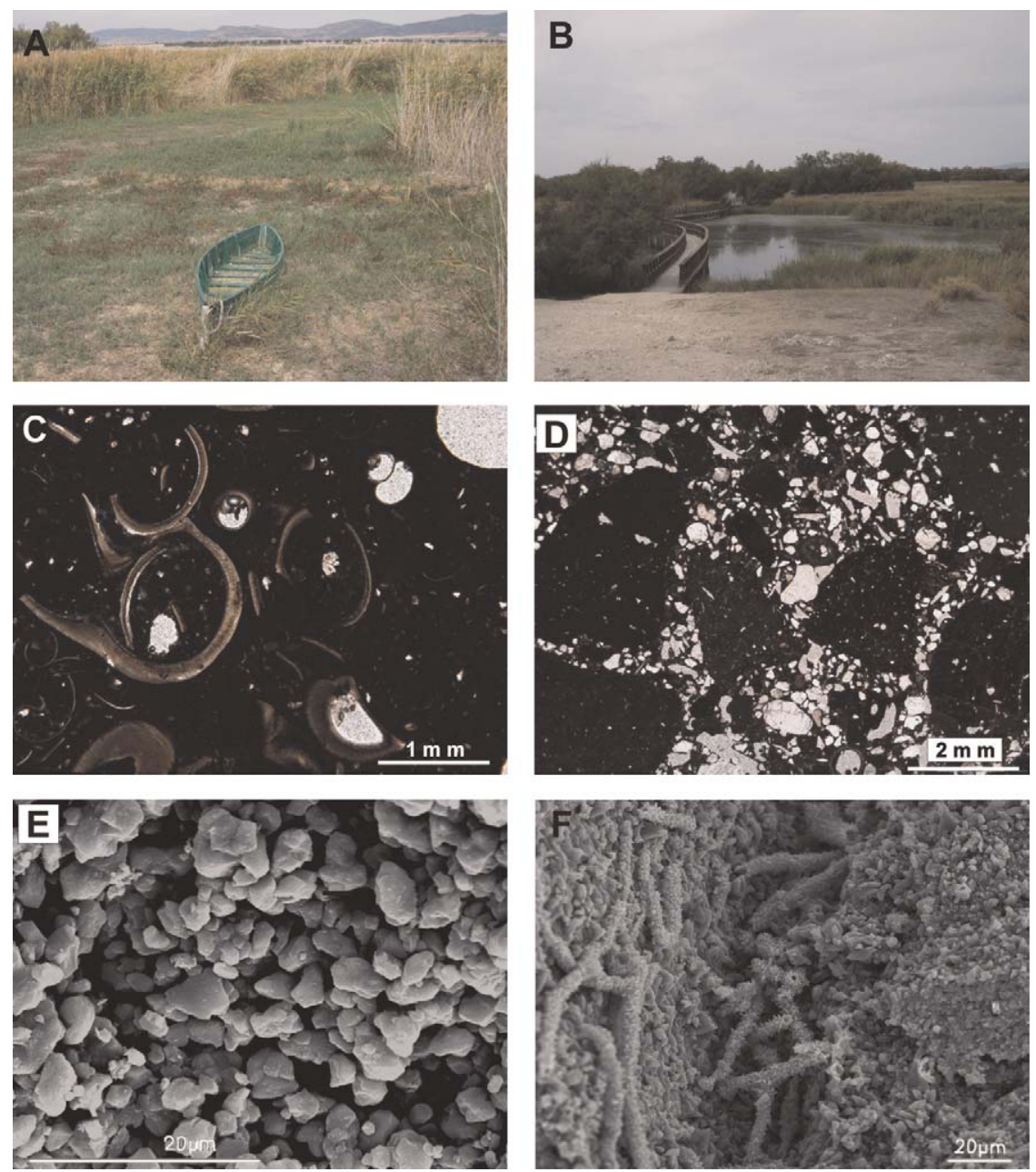

Figure 4 Palustrine facies and environments from the Las Tablas de Daimiel wetland. (A) View of a dry area of Las Tablas. The area around the boat was wet few years ago. Reeds are the most characteristic vegetation. (B) View of an active, flooded area of Las Tablas. The depth of water is less than $1 \mathrm{~m}$. (C) Indurated wackestones with bioclasts. (D) Packstone of intraclasts, formed by desiccation of the previous limestones and their later reworking. Quartz grains are also common. This facies probably indicates prolonged subaerial exposure. (E) SEM image of the palustrine mudstone facies, which are very porous and consist of very fine sub-euhedral crystals. (F) SEM image of microbial calcified filaments in a palustrine limestone, indicating the role of vegetation in the formation of these facies. 
However, more studies are needed in order to increase the insight into wetland deposition.

\section{Environmental Controls on Palustrine DEPOSITION}

Tectonism, climate and eustasy are the main factors operating in the marine realm. In terrestrial environments, eustasy drives the base level which is critical to fluvial systems, erosion and sedimentation rates. Eustasy is important to basins even far away from, but connected with, the ocean, and some examples will be discussed later. However, eustasy does not directly control sedimentary deposition in a number of examples, including sedimentation of palustrine deposits. In basins lacking a clear connection to the oceans, two additional factors, viz. hydrology and supply/sources of carbonates, have to be considered. Because these factors are integrated, it is difficult in many cases to distinguish the specific effects of climate, hydrology and tectonism.

Palustrine carbonates are obviously sensitive to climate. There must be sufficient rainfall to carry the carbonate-rich solutions either in the surface waters or in the groundwater (De Wet et al., 1998). Very arid or very humid climates do not favour carbonate deposition in lakes (Cecil, 1990), whereas semi-arid to sub-humid climates with marked seasonality are more appropriate (Platt and Wright, 1991; Sanz et al., 1995; GierlowskiKordesch, 1998). Palustrine carbonates are sensitive to fluctuations in humidity. Therefore, palustrine facies and sequences may vary according to the climate regime (Platt and Wright, 1992). In sub-humid climates, palustrine deposits contain more organic matter - such as in the Miocene of the Teruel Graben (Alonso-Zarza and Calvo, 2000) - which may develop into coals, such as in the Oligocene of the Ebro Basin (Cabrera and Sáez, 1987). In contrast, semi-arid climates are characterised by wide pseudomicrokarst development on top of the successions, and organic matter is rarely preserved, as in the Upper Jurassic of the Morrison Formation (Dunagan and Turner, 2004). More arid climates favour the presence of evaporite nodules within the palustrine carbonates, or palustrine carbonates dominated by dolomite (Sanz et al., 1999).

Climate also affects the carbonate precipitation rate, both of inorganic precipitation (because of temperature effects in the water body and evaporation) and of biogenically produced carbonate (Kelts and Hsü, 1978; Platt and Wright, 1991; Verrecchia, 2007). In palustrine environments, the climate also plays a role in the run-off in the catchment area and hence in sediment supply, which is typically siliciclastic in composition. Thus climate change will impact upon the short- to medium-term sedimentary 
successions (De Wet et al., 2002; Sáez and Cabrera, 2002). However, in many cases it is difficult to evaluate the relative roles of climate and tectonism separately, as discussed below.

In non-marine basins, tectonism seems to be the main agent responsible for generating accommodation space for deposition (De Wet et al., 1998), and so controls the long-term stratigraphic signal (Sáez and Cabrera, 2002). In contrast, climate is considered the main factor in the development of short-term sedimentary cycles (De Wet et al., 2002; Luzón et al., 2002), because of its influence on sediment and water supply (Carroll and Bohacs, 1999; Bohacs et al., 2000). The interplay between climate and tectonism has been used to establish a complete framework of lacustrine basins using a sequence-stratigraphy approach. This framework establishes three types of lake basins: overfilled basins characterised by the association of fluvial/ lacustrine facies, balance-fill basins dominated by the association of fluctuating-profundal facies and underfilled basins characterised by an evaporite facies association (Bohacs et al., 2000). Palustrine carbonates may be present in any of the three types, but are more prominent in overfilled basins and in the highstand depositional systems of balanced-fill and underfilled basins. In this respect, palustrine carbonates are common in the latest stages of closed-basin filling where the carbonates onlap the basin margins (Alonso Zarza et al., 1992). Under such conditions, the reduction in relief, caused by a progressive decrease of tectonic activity along the basin margins, or the change of topography due to basin infilling, results in reduced siliciclastic sediments input, thus favouring carbonate deposition. In addition, filled basins have low-relief terrains that favour shallow water tables and allow near-surface groundwater to degas or to be concentrated by evaporation (thereby producing groundwater carbonates), or to intersect the land surface and cause the development of shallow, low-gradient lakes or discharge wetlands.

The lack of sediment input is the likely cause for the development of vertically stacked palustrine successions because the lack of significant alluvial/fluvial activity promotes continuity of the lake-wetland water bodies. Examples include the Cretaceous Rupelo Formation of the Cameros Basin (Platt, 1989) and the Late Cretaceous-Palaeogene of southern France (Freytet and Plaziat, 1982). The palustrine deposits represent stages of reduced accommodation space and, tentatively, highstand depositional systems. In the stratigraphic framework proposed by Carroll and Bohacs (1999) and Bohacs et al. (2000), this situation may be relatively common in overfilled basins.

In cases where fluvial systems occasionally reach the shallow water body, pond-wetland carbonates are interbedded with clastic alluvial deposits. Examples include the pond deposits of the Eocene Guarga Formation in the Pyrenees (Nickel, 1982), and some Miocene successions in the Madrid Basin (Sanz et al., 1995). In both cases, palustrine carbonate lenses occur 
interbedded with red alluvial mudstones. The latter represent distal fan facies and/or floodplain deposits, while the carbonate lenses were deposited during periods or in areas of reduced clastic sedimentation. This is common in stages of high accommodation space that favour high levels of storage of floodplain sediments, resulting in isolated channels, weakly developed soils (Wright and Marriott, 1993) and ponds. Together, these characterise transgressive depositional systems. Balance-fill basins may be the more favourable to contain pond deposits because of the common interfingering within them of fluvial and shallow-lake environments.

In the above situations and in most basins that contain thick lacustrine and palustrine carbonate sequences, the main control on the accommodation space and drainage patterns is tectonism. The Calama Basin in Chile is an example of an active tectonic setting where tectonism determined the location and the type of lacustrine environment, which included fluviolacustrine diatomite, palustrine carbonate, massive anhydrite and alluvial fan deposits (May et al., 1999). The change from permanent diatomite to palustrine (around $6 \mathrm{Ma}$ ) together with a decrease in run-off in the centre of the basin is interpreted as the result of a more efficient drainage network. The present authors indicated that it is unlikely that lacustrine systems record low-order climatic changes in tectonically active settings. Similarly, Sáez and Cabrera (2002) discussed how low-order lacustrine sequence transitions were caused by significant increases in the volume of lake water, without palaeobotanical evidence for a climatic change. The sequence transition in the As Pontes Basin is explained by either the incremental addition of accommodation space by increasing activity of the strike-slip fault systems, or the enlargement of the catchment area by simple headward extension of the drainage network.

On a smaller scale (decimetres to a few metres), the development of palustrine sequences responds to the relationship between the subsidence rate and the sediment fill of the basin. In alluvial basins, pulses of subsidence due to the tilting of the basin floor may cause the redistribution of lake water, resulting in a local rise of the water table and the rapid formation of a shallow lake. Subsequent infill of the lake favours the exposure of lacustrine carbonates and their pedogenic modification (Figure 5). These sequences are common in the Cretaceous of the Serranía de Cuenca (GierlowskiKordesch et al., 1991) and in the Teruel Graben (Alonso-Zarza and Calvo, 2000). In contrast, the equilibrium between tectonic subsidence and sedimentation favours a slow, but continuous aggradation of the floodplain areas and a gradual rise of the water table. Under this regime, a gradual vertical transition from palaeosols developed in floodplain mudstones to palustrine carbonates is commonly seen, as in the carbonate pond deposits of the Madrid Basin (Sanz et al., 1995) and the Almazán Basin (Huerta and Armenteros, 2005). For more recent wetlands situated in rift areas, such as the Loboi Swamp in Kenya, Ashley et al. (2004) proposed that the change 
A: Normal sequences:

Progressive agraddation

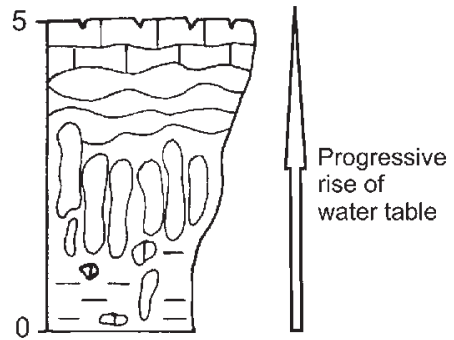

C: Carbonate-filled channels

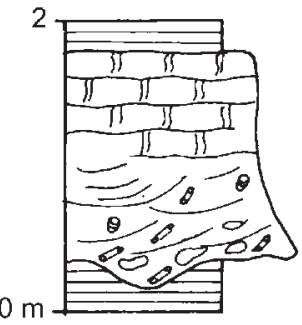

B: Reverse sequences:

Tittling of the basin floor
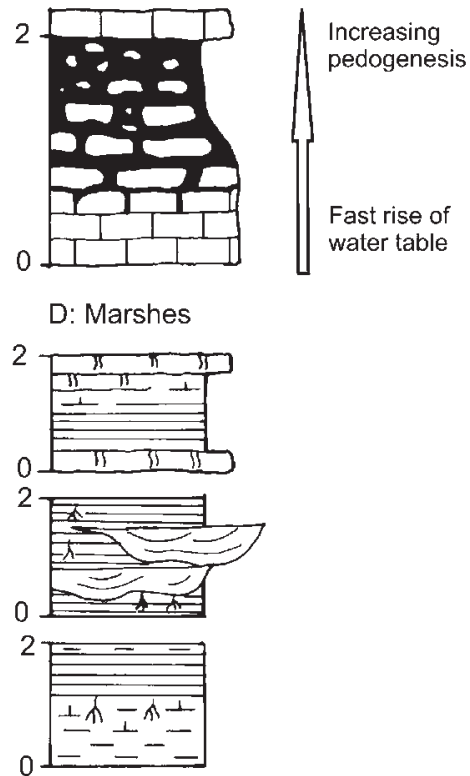

\begin{tabular}{|c|c|c|c|c|c|}
\hline $\begin{array}{ll}1 \\
4\end{array}$ & Biomicrite beds & $\frac{\pi n}{\pi}$ & Bioturbated limestones & $\theta$ & Mottled limestones \\
\hline - - & Red clays & $\perp+$ & Green marls and clays & & Organic-rich marlstones and clays \\
\hline 000 & Vertical carbonate nodules & 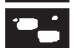 & Red soil matrix & $E$ & Carbonate-filled channels \\
\hline nn & Root traces & 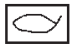 & Ostracods & $\infty$ & Charophytes \\
\hline 5 & Intraclasts & $\mathrm{DD}$ & Sparse carbonate nodules & 69 & Phytoclasts \\
\hline
\end{tabular}

Figure 5 Palustrine deposits from the Teruel Basin. (A) and (B) show different arrangements of facies, depending on how fast the water table reaches the surface. Some carbonate-filled channels (C) and marshes (D) are commonly associated with these palustrine-wetland environments.

to wetter conditions during the Late Holocene favoured the development and growth of the wetland. However, the lowering of the surface near or at the water table may be controlled by tectonic subsidence pulses, as seen at a small scale (metres) in the Neogene deposits of the Teruel Graben (AlonsoZarza and Calvo, 2000), or at a large scale (a hundred metres) in the Cretaceous of the Aguilar de Campo Formation (Hernández et al., 1998).

The possibility of identifying climatic signals in short-term lacustrine sequences has been the objective of several recent studies (e.g., Abdul-Aziz et al., 2000), which conclude that some sequences may correspond to astronomical precession cycles. In a study of the cyclicity of Tertiary 
deposits of the Ebro Basin, Luzón et al. (2002) showed that marginal lacustrine deposits are not suitable for identifying the effects of climatic cycles because non-periodic processes can play a more important role in the sedimentation, modifying the original sedimentological features. In open lake areas of the same lacustrine system, spectral analysis clearly indicates precession-related climatic cyclicity. Although there is common agreement on the role of climate in creating short- to medium-term (up to 10-20 m thick) sedimentary lacustrine sequences (Arenas and Pardo, 1999; Armenteros and Huerta, 2006, amongst many others), care must be taken when interpreting the causes of the cyclicity, because short-term subsidence episodes may also give place to the formation of metre-scale sequences (Huerta and Armenteros, 2005).

Cyclicity can also reflect groundwater activity. One interesting example comes from the Lower Pliocene Hagul Formation of the East Cairo District, Egypt, described by Khalaf and Gaber (2008). Here, more than 10 depositional cycles are recognised which represent alluvial sedimentation, followed by calcretisation, and formation of palustrine carbonates. The distal alluvial plain setting received alluvial sediment during more humid intervals, with pedogenic calcretes forming during semi-arid climates with episodic precipitation. During sub-humid phases, the groundwater levels gradually rose and groundwater calcrete accumulated, followed by shallow palustrine carbonate wetlands.

Climate and tectonism also determine the topography, the hydrology of the lake (open/closed), the mechanisms of water supply and the sources of the carbonate and calcium ions within the lake.

In the Cenozoic deposits of the Ebro Basin, the asymmetry in the distribution of shallow-lake deposits, which are dominated by evaporites in the southern Iberian margin and palustrine carbonates in the North (Pyrenean margins), reflects the strong hydrological contrast and different topographic gradients. The Iberian margin has a low gradient and smaller water supply, whereas the Pyrenean margins have steep gradients and a permanent water supply (Arenas and Pardo, 1999). The presence within lake basins of topographic highs can divide the basins and favour the development of palustrine deposits in the shallower parts; in the Cañadón Asfalto Formation in Argentina, for example, a bioherm ridge acted as a physiographic barrier (Cabaleri and Armella, 2005).

The mechanism of water supply to the lake plays an important role in determining the lake chemistry and therefore the mineralogy of the sediments, as well as later transformations during early diagenesis. The relative contribution of groundwater and surface water to the inundated area is considered important for distinguishing between lakes and wetlands (Currey, 1990). According to Dunagan and Turner (2004), many wetlands seem to be fed primarily by groundwater, but may receive surface water by sheet flows; in contrast, lakes are fed mainly by surface water from run-off, 
rivers and streams that enter the basin, with a secondary groundwater contribution. However, even in modern environments this differentiation is difficult to make because the nature of the water supply may vary with time as a consequence of climate and even tectonism. Some recent wetlands such as the Loboi Swamp are fed by springs (Ashley et al., 2004); in addition, the Las Tablas wetlands are fed by a combination of springs, rivers and run-off (Álvarez-Cobelas and Cirujano, 1996).

Commonly, as in the Eocene of South Dakota, palustrine limestones are found near fault zones spatially associated with palaeogroundwater or spring deposits. Some of these carbonates formed behind tufa barrages (Evans, 1999), and their occurrence supports the importance of groundwater supply in shallow lacustrine-palustrine environments. During the Upper Triassic, the discharge of water through fault-bounded spring systems favoured the development of an extensive lake system in Poland; travertines formed near the springs, whereas palustrine carbonates were deposited in more distal areas (Szulc et al., 2006). Hernández et al. (1998) have recognised hotwater spring travertines fed through fault systems in the NE of Spain. This is one of the main feeding mechanisms to the palustrine-lacustrine system. Unfortunately, the preservation potential of the spring conduits and even of their deposits is limited, and proving a spring-fed source for the palustrine carbonates is therefore difficult in many cases.

A purely meteoric, run-off supply gives rise to lake waters with a low solute content. If there is any carbonate precipitation in such lakes, it is usually mainly calcite. However, chemical precipitation may be inhibited or diluted by clastic input that may constitute the main infill of the lake. If the lake is mainly fed by groundwater, directly or via springs, a more complex lake geochemistry can be expected, and the mineralogy of the palustrine deposits will depend on the composition of the groundwaters. Factors such as the distance that the groundwater has flowed, the composition of the catchment areas and the ratio of rock/water interaction and evaporation rates all control groundwater composition and therefore the mineralogy of the primary precipitates and their possible transformation during early diagenesis (Arakel and McConchie, 1982).

Low-Mg calcite is a common precipitate if the groundwater flow path is relatively short, or if the catchment area is dominated by low-Mg calcite, and little evaporation occurs. Dolomite and gypsum may form from more evolved groundwater due to removal of less-soluble phases during flow towards the lake or within the lake itself (Wright and Sandler, 1994; Calvo et al., 1995). However, the composition of groundwaters and the formation of other precipitates such as dolomite, gypsum or Mg clays depend not only on the hydrology but also on the climate and/or the presence of source rocks containing evaporites.

Many of the documented examples of palustrine carbonates developed in basins surrounded by hinterlands dominated by carbonate rocks. There are 
a number of examples on the Iberian Peninsula (Platt, 1989; Alonso-Zarza et al., 1992, amongst many others) and in the Triassic of Pennsylvania (De Wet et al., 1998). However, this is not always a prerequisite for lacustrine-palustrine carbonate sedimentation. For example, in the Upper Palaeozoic of the Pyrenees, lacustrine carbonates are interbedded with pyroclastic layers (Valero, 1993). The weathering of calc-alkaline volcanic rocks in the catchment area favoured low to moderate calcite production in adjacent lakes. Nevertheless, the presence of carbonates underlying the lakes or in the basin margins notably contributes to carbonate precipitation within the lakes for two main reasons: (1) it favours high carbonate concentrations in the surface and groundwater (Gierlowski-Kordesch, 1998) and (2) it favours a low siliciclastic input; both control the carbonate production within the lake (Cohen, 1989). Some well-known lacustrine and palustrine deposits and even palustrine-saline and carbonate lakes are found in association with karstic systems, either in depressions of the karst or in areas with supplies by the output of the karstic waters (Poyato et al., 1998; Pérez et al., 2002; Alonso-Zarza et al., 2006).

Palustrine carbonates have also been recorded in marginal-marine settings, specifically in coastal-plain systems, as in the Eocene of the Isle of Wight off England (Armenteros and Daley, 1998), and in the Cretaceous of Croatia (Dini et al., 1998) and Spain (Martín-Chivelet and Giménez, 1992); they may cover thousands of square kilometres (MacNeil and Jones, 2006). It has been argued that the Florida Everglades may represent a possible modern analogue for palustrine deposition (Platt and Wright, 1992). However, there are few documented examples of such carbonates and it is possible that other cases exist that have been attributed instead to calcretes or marine deposits. An additional complication might be that palustrine carbonates may overprint marine macrophytic deposits (such as mangrove facies) during shallowing-upwards intervals (Wright and Azeredo, 2006). In their study of palustrine carbonates from the Devonian of the Northwest Territories of Canada, MacNeil and Jones (2006) stressed the importance of these coastal palustrine carbonates because of their implications for sequence-stratigraphic analysis; that is, they indicate subaerial unconformities and sequence boundaries, similar to calcretes and karsts.

\section{CONCLUSIONS}

Palustrine deposits are a distinctive type of non-marine carbonates that are associated with hard-water lake-margin and wetland settings. They represent the modification of carbonate muds by wetting and drying and more prolonged subaerial exposure, and pedogenesis associated with macrophytes, and so are effectively a post-Silurian phenomenon. They are part of a continuum of carbonate facies related to hydrological systems, 
closely related to groundwater calcretes, tufas and travertines, wetlands and shallow-lake deposits. Palustrine carbonates are commonly, but not always, associated with the late stages of basin filling, reflecting limited tectonic relief development, limited accommodation-space creation, limited terrigenous sediment input and low-relief landscapes where the position of the water table is a critical control on carbonate accumulation. They are sensitive to subtle hydrological changes in basins and so respond to both climatic and tectonic effects, resulting in the need to critically separate such effects when interpreting climatic signals. Despite their relatively common occurrence in the stratigraphic record, modern analogues are very rare. Therefore, it is imperative that we track down active examples in order to release all the data locked in the ancient palustrine record.

\section{ACKNOWLEDGEMENTS}

This work was funded by project CGL-2008-05584-C02-02 from the Spanish Ministerio de Ciencia e Innovación and CCG07-UCM/AMB2299-910404 from CM-UCM. Dr. Dunagan is thanked for his critical revision of the manuscript. L. H. Tanner and T. van Loon have contributed to the careful editing of this contribution.

\section{REFERENCES}

Abdul-Aziz, H., Hilgen, F., Krijgsman, W., Sanz, E., Calvo, J.P., 2000. Astronomical forcing of sedimentary cycles in the middle to late Miocene continental Calatayud Basin (NE Spain). Earth and Planetary Science Letters 177, 9-22.

Alonso-Zarza, A.M., 2003. Palaeoenvironmental significance of palustrine carbonates and calcretes in the geological record. Earth-Science Reviews 60, 261-298.

Alonso-Zarza, A.M., Calvo, J.P., 2000. Palustrine sedimentation in an episodically subsiding basin: the Miocene of the northern Teruel Graben (Spain). Palaeogeography, Palaeoclimatology, Palaeoecology 160, 1-21.

Alonso-Zarza, A.M., Calvo, J.P., García del Cura, M.A., 1992. Palustrine sedimentation and associated features - grainification and pseudo-microkarst - in the Middle Miocene (Intermediate Unit) of the Madrid Basin, Spain. Sedimentary Geology 76, 43-61.

Alonso-Zarza, A.M., Dorado-Valiño, M., Valdeolmillos-Rodríguez, A., Ruiz-Zapata, M.B., 2006. A recent analogue for palustrine carbonate environments: the Quaternary deposits of Las Tablas de Daimiel wetlands, Ciudad Real, Spain. In: Alonso-Zarza, A.M., Tanner, L.H. (Eds), Paleoenvironmental Record and Applications of Calcretes and Palustrine Carbonates. Geological Society of America, Special Paper 416, pp. $153-168$.

Alonso-Zarza, A.M., Tanner, L.H. (Eds), 2006. Paleoenvironmental Record and Applications of Calcretes and Palustrine Carbonates. Geological Society of America, Special Paper 416, 239 pp.

Alonso-Zarza, A.M., Wright, V.P., 2010. Calcretes. In: Alonso-Zarza, A.M., Tanner, L.H. (Eds), Continental Carbonates. Developments in Sedimentology, 61, pp. 225-268.

Álvarez-Cobelas, M., Cirujano, S. (Eds), 1996. Las Tablas de Daimiel. Ecología Acuática y Sociedad. Organismo Autónomo Parques Naturales, Madrid, 368 pp. 
Anadón, P., Utrilla, R., Vázquez, A., 2000. Use of charophyte carbonates as proxy indicators of subtle hydrological and chemical changes in marl lakes: example from the Miocene Bicorb Basin, eastern Spain. Sedimentary Geology 133, 325-347.

Arakel, A.V., McConchie, D., 1982. Classification and genesis of calcrete and gypsite lithofacies in palaeodrainage basins of inland Australia and their relationship to carnotite mineralization. Journal of Sedimentary Petrology 52, 1147-1170.

Arenas, C., Cabrera, L., Ramos, L., 2007. Sedimentology and tufa facies and continental microbialites from the Palaeogene of Mallorca Island (Spain). Sedimentary Geology 197, $1-22$.

Arenas, C., Casanova, J., Pardo, G., 1997. Stable-isotope characterization of the Miocene lacustrine systems of Los Monegros (Ebro Basin, Spain): palaeogeographic and palaeoclimatic implications. Palaeogeography, Palaeoclimatology, Palaeoecology 128, $133-155$.

Arenas, C., Pardo, G., 1999. Latest Oligocene-Late Miocene lacustrine systems of the northcentral part of the Ebro Basin (Spain): sedimentary facies model and palaeogeographic synthesis. Palaeogeography, Palaeoclimatology, Palaeoecology 151, 127-148.

Armenteros, I., Daley, B., 1998. Pedogenic modification and structure evolution in palustrine facies as exemplified by Bembridge Limestone (late Olocene) of Isle of Wight, southern England. Sedimentary Geology 119, 275-295.

Armenteros, I., Daley, B., García, E., 1997. Lacustrine and palustrine facies in the Bembridge Limestone (late Eocene, Hamshire Basin) of Isle of Wight, southern England. Palaeogeography, Palaeoclimatology, Palaeoecology 128, 111-132.

Armenteros, I., Huerta, P., 2006. The role of clastic sediment influx in the formation of calcrete and palustrine facies: a response to paleogeographic and climatic conditions in the southeastern Tertiary Duero basin (northern Spain). In: Alonso-Zarza, A.M., Tanner, L.H. (Eds), Paleoenvironmental Record and Applications of Calcretes and Palustrine Carbonates. Geological Society of America, Special Paper 416, pp. 119-132.

Ashley, G.M., Maitima Mworia, J., Muasya, A.M., Owens, R.B., Driese, S.G., Hover, V.C., Renaut, R.W., Goman, M.F., Mathai, S., Blatt, S.H., 2004. Sedimentation and recent history of a freshwater wetland in a semi-arid environment: Loboi Swamp, Kenya, East Africa. Sedimentology 51, 1-21.

Bohacs, K.M., Carroll, A.R, Neal, J.E., Mankiewicz, P.J., 2000. Lake-basin type, source potential, and hydrocarbon character: an integrated-sequence-stratigraphic-geochemical framework. In: Gierlowski-Kordesch, E.H., Kelts, K.R. (Eds), Lake Basins through Space and Time. AAPG Studies in Geology 46, pp. 3-34.

Bowen, G.J., Bloch, J.I., 2002. Petrography and geochemistry of floodplain limestones from the Clarks Fork Basin, Wyoming, USA: carbonate deposition and fossil accumulation on a Paleocene-Eocene floodplain. Journal of Sedimentary Research $72,46-58$.

Bustillo, M.A., Alonso-Zarza, A.M., 2007. Overlapping of pedogenesis and meteoric diagenesis in distal alluvial and shallow lacustrine deposits in the Madrid Miocene Basin, Spain. Sedimentary Geology 198, 255-271.

Cabaleri, N.G., Armella, C., 2005. Influence of a biohermal belt on the lacustrine sedimentation of the Cañadón Asfalto Formation (Upper Jurassic, Chubut province, Southern Argentina). Geologica Acta 3, 205-214.

Cabrera, L., Sáez, A., 1987. Coal deposition in carbonate-rich shallow lacustrine systems: the Calaf and Mequinenza sequences (Oligocene, eastern Ebro Basin, NE Spain). Journal of the Geological Society 144, 451-461.

Calvo, J.P., Jones, B.F., Bustillo, M., Fort, R., Alonso-Zarza, A.M., Kendall, C., 1995. Sedimentology and geochemistry of carbonates from lacustrine sequences in the Madrid Basin, Central Spain. Chemical Geology 123, 173-191. 
Carroll, A.R., Bohacs, K.M., 1999. Stratigraphic classification of ancient lakes: balancing tectonic and climatic controls. Geology 27, 99-102.

Cecil, C.B., 1990. Paleoclimate controls on stratigraphic repetition of chemical and siliciclastic rocks. Geology 18, 533-536.

Cohen, A.S., 1989. Facies relationships and sedimentation in large rift lakes and implications for hydrocarbon exploration: examples from Lakes Turkana and Tanganyka. Palaeogeography, Palaeoclimatology, Palaeoecology 70, 65-80.

Cowardin, L.M., Carter, V., Golet, F.C., LaRoe, E.T., 1979. Classification of Wetlands and Deepwater Habitats of the United States. US Fish and Wildlife Service FWS/OBS79/31, $131 \mathrm{pp}$.

Currey, D.R., 1990. Quaternary palaeolakes in the evolution of semidesert basins, with special emphasis on Lake Bonneville and the Great Basin, USA. Palaeogeography, Palaeoclimatology, Palaeoecology 76, 189-214.

De Wet, C., Mora, C.I., Gore, P.J.W., Gierlowski-Kordesch, E., Cucolo, S.J., 2002. Deposition and geochemistry of lacustrine and spring carbonates in Mesozoic rift basins, Eastern North America. In: Sedimentation in Continental Rifts. SEPM Special Publication 73, pp. 309-325.

De Wet, C., Yocum, D.A., Mora, C., 1998. Carbonate lakes in closed basins: sensitive indicators of climate and tectonics: an example from the Gettysburg Basin (Triassic), Pennsylvania, USA. In: Role of Eustasy, Climate and Tectonism in Continental Rocks. SEPM Special Publication 59, pp. 191-209.

DGOH, 1991. Estudio de las Zonas Húmedas de la España Peninsular. Inventario y tipificación. Documento de síntesis. Madrid, Dirección General de Obras Hidráulicas, Ministerio de Obras Públicas y Transportes, $80 \mathrm{pp}$.

Dini, M., Tunis, G., Venturini, S., 1998. Continental, brackish and marine carbonates from the Lower Cretaceous of Kolone-Barbariga (Istria, Croatia): stratigraphy, sedimentology and geochemistry. Sedimentary Geology 140, 245-269.

Dorado Valiño, M., Valdeolmillos, A., Ruiz Zapata, M.B., Gil García, M.J., Bustamante, I., 2002. Climatic changes since the Late-glacial/Holocene transition in La Mancha Plain (South-central Iberian Peninsula, Spain) and their incidence on Las Tablas de Daimiel marshlands. Quaternary International 93, 73-94.

Dunagan, S.P., Driese, S.G., 1999. Control of terrestrial stabilization on late Devonian palustrine carbonate deposition: Catskill Magnafacies, New York, USA. Journal of Sedimentary Research 69, 772-783.

Dunagan, S.P., Turner, C.E., 2004. Regional paleohydrologic and paleoclimatic settings of wetland/lacustrine depositional systems in the Morrison Formation (Upper Jurassic), Western Interior, USA. Sedimentary Geology 167, 269-296.

Esteban, M., Klappa, C.F., 1983. Subaerial exposure environments. In: Scholle, P.A., Bebout, D.G., Moore, C.H. (Eds), Carbonate Depositional Environments. American Association of Petroleum Geologists Memoir 33, pp. 1-96.

Evans, J.E., 1999. Recognition and implications of Eocene tufas and travertines in the Chadron Formation, White River Group, Badlands of South Dakota. Sedimentology 46, $771-789$.

Ford, T.D., Pedley, H.M., 1996. A review of tufa and travertine deposits of the world. Earth-Science Reviews 41, 117-175.

Freytet, P., 1965. Sédimentation microcyclothématique avec croûte zonaire à algues dans le Calcaire de Veauce de Chauffour-Ethrechy (S.-et-O.). Bulletin de la Societé Géologique de France 7, 309-313.

Freytet, P., 1971. Paléosols résiduels et paleosols alluviaux hydromorphes dans le Crétacé Supérieur et l'Eocene basal en Languedoc. Revue de Géographie Physique et de Géologie Dynamique 2 (13), 245-268. 
Freytet, P., 1973. Petrography and paleo-environment of continental carbonate deposits with particular reference to the Upper Cretaceous and Lower Eocene of Languedoc (Southern France). Sedimentary Geology 10, 25-60.

Freytet, P., 1984. Les sédiments lacustres carbonatés et leurs transformations par émersion et pédogenèse. Importance de leur identification pour les reconstitutions paéogéographiques. Bulletin des Centres de Recherche Exploration-Production Elf-Aquitaine 8, $223-246$.

Freytet, P., Plaziat, J.C., 1982. Continental carbonate sedimentation and pedogenesis - Late Cretaceous and Early Tertiary of southern France. Contributions to Sedimentology (E. Schweizerbart'sche Verlagsbuchhandlung, Stuttgart) 12, 213 pp.

Freytet, P., Verrecchia, E.P., 2002. Lacustrine and palustrine carbonate petrography: an overview. Journal of Paleolimnology 27, 221-237.

Gierlowski-Kordesch, E., Gómez Fernández, J.C., Meléndez, N., 1991. Carbonate and coal deposition in an alluvial-lacustrine setting: Lower Cretaceous (Weald) in the Iberian Range (east-central Spain). In: Anadón, P., Cabrera, L., Kelts, K. (Eds), Lacustrine Facies Analysis. Special Publication International Association of Sedimentologists 13, pp. $109-125$.

Gierlowski-Kordesch, E.H., 1998. Carbonate deposition in an ephemeral siliciclastic alluvial system: Jurassic Shuttle Meadow Formation, Newark Supergroup, Hartford Basin, USA. Palaeogeography, Palaeoclimatology, Palaeoecology 140, 161-184.

Gierlowski-Kordesch, E.H., 2010. Lacustrine carbonates. In: Alonso-Zarza, A.M., Tanner, L.H. (Eds), Continental Carbonates. Developments in Sedimentology, 61, pp. 1-102.

Gierlowski-Kordesch, E.H., Kelts, K. (Eds), 2000. Lake Basins through Space and Time. AAPG Studies in Geology 46, 648 pp.

Hernández, J.M., Diéguez, C., Pujalte, V., Robles, S., Wright, V.P., 1998. Recognition of fossil travertine accumulations in the Aguilar Fm. (Kimmeridgian-Berriasian of Palencia and Burgos): palaeoecological and palaeohydrological implications. Geogaceta 24, $167-170$.

Huerta, P., Armenteros, I., 2005. Calcrete and palustrine assemblages on a distal alluvialfloodplain: a response to local subsidence (Miocene of the Duero Basin, Spain). Sedimentary Geology 177, 235-270.

Kelts, K.R., Hsü, K., 1978. Freshwater carbonate sedimentation. In: Lerman, A. (Ed.), Lakes - Chemistry, Geology, Physics. Springer, New York, NY, pp. 295-323.

Khalaf, F.I., Gaber, A.S., 2008. Occurrence of cyclic palustrine and calcrete deposits within the Lower Pliocene Hagul Formation, East Cairo District, Egypt. Journal of African Earth Sciences 51, 298-312.

Luzón, A., González, A., Muñoz, A., Sánchez-Valverde, B., 2002. Upper Oligocene-Lower Miocence shallowing-upward lacustrine sequences controlled by periodic and non-periodic processes (Ebro Basin, northeastern Spain). Journal of Paleolimnology 28, 441-456.

MacNeil, A.J., Jones, B., 2006. Palustrine deposits on a Late Devonian coastal plain sedimentary attributes and implications for concepts of carbonate sequence stratigraphy. Journal of Sedimentary Research 76, 292-309.

Martín-Chivelet, J., Giménez, R., 1992. Palaeosols in microtidal carbonate sequences, Sierra de Utiel Formation, Upper Cretaceous, SE Spain. Sedimentary Geology 81, 125-145.

Marty, D., Meyer, C.A., 2006. Depositional conditions of carbonate-dominated palustrine sedimentation around the K-T boundary (Faciès Rognacien, northeastern Pyrenean foreland, southwestern France). In: Alonso-Zarza, A.M., Tanner, L.H. (Eds), Paleoenvironmental Record and Applications of Calcretes and Palustrine Carbonates. Geological Society of America, Special Paper 416, pp. 153-168.

May, G., Hartley, A.J., Stuart, F.M., Chong, G., 1999. Tectonic signatures in arid continental basins: an example from the Upper Miocene-Pleistocene, Calama Basin, 
Andean forearc, northern Chile. Palaeogeography, Palaeoclimatology, Palaeoecology $151,55-77$.

Mazzullo, S.J., Birdwell, B.A., 1989. Syngenetic formation of grainstones and pisolites from fenestral carbonates in peritidal settings. Journal of Sedimentary Petrology 59, 605-611.

Mitsch, W.J., Gosselink, J.G., 1993. Wetlands (2nd Edition). New York, Van Nostrand Reinhold, $722 \mathrm{pp}$.

Mount, J.F., Cohen, A.S., 1984. Petrology and geochemistry of rhizoliths from PlioPleistocene fluvial and marginal lacustrine deposits, east Lake Turkana, Kenya. Journal of Sedimentary Petrology 54, 263-275.

Nickel, E., 1982. Alluvial-fan-carbonate facies with evaporites, Eocene Guarga Formation, Southern Pyrenees, Spain. Sedimentology 29, 761-796.

Pérez, A., Luzón, A., Roc, A.C., Soria, A.R., Mayayo, M.J., Sánchez, J.A., 2002. Sedimentary facies distribution and genesis of a recent carbonate-rich saline lake: Gallocanta Lake, Iberian Chain, NE Spain. Sedimentary Geology 148, 185-202.

PiPujol, M.D., Buurman, P., 1997. Dynamics of iron and calcium carbonate redistribution and palaeohydrology in middle Eocene alluvial paleosols of the southeast Ebro Basin margin. Palaeogeography, Palaeoclimatology, Palaeoecology 134, 87-107.

Platt, N.H., 1989. Lacustrine carbonates and pedogenesis: sedimentology and origin of palustrine deposits from the Early Cretaceous Rupelo Formation, W Cameros Basin, N Spain. Sedimentology 36, 665-684.

Platt, N.H., Wright, V.P., 1991. Lacustrine carbonates: facies models, facies distribution and hydrocarbon aspects. In: Anadón, P., Cabrera, L., Kelts, K. (Eds), Lacustrine Facies Analysis. Special Publication International Association of Sedimentologists 13, pp. $57-74$.

Platt, N.H., Wright, V.P., 1992. Palustrine carbonates at the Florida Everglades: towards an exposure index for the fresh-water environment. Journal of Sedimentary Petrology 62, $1058-1071$.

Plaziat, J.C., Freytet, P., 1978. Le pseudo-microkarst pédologique: un aspect particulier des paléo-pédogenèses développées sur les dépôts calcaires lacustres dans le Tertiaire du Languedoc. Comptes Rendus de l'Academie des Sciences, Paris 286, 1661-1664.

Poyato, F.J., Talbot, M.R., Fregenal-Martínez, M.A., Meléndez, N., Wenz, S., 1998. First isotopic and multidisciplinary evidence for nonmarine coelacanths and pycnodontiform fishes: palaeoenvironmental implications. Palaeogeography, Palaeoclimatology, Palaeoecology 144, 65-84.

Rodríguez-Aranda, J.P., Calvo, J.P., 1998. Trace fossils and rhizoliths as a tool for sedimentological and palaeoenvironmental analysis of ancient continental evaporite succesions. Palaeogeography, Palaeoclimatology, Palaeoecology 140, 383-399.

Sáez, A., Cabrera, L., 2002. Sedimentological and palaeohydrological responses to tectonics and climate in a small, closed, lacustrine system: Oligocene As Pontes Basin (Spain). Sedimentology 49, 1073-1094.

Sanz, E., Hoyos, M., Calvo, J.P., Rouchy, J.M., 1999. Nodular anhydrite growth controlled by pedogenic structures in evaporite lake formations. Sedimentary Geology 125, 195-203.

Sanz, M.E., Alonso-Zarza, A.M., Calvo, J.P., 1995. Carbonate pond deposits related to semi-arid alluvial systems: examples from the Tertiary Madrid Basin, Spain. Sedimentology 42, 437-452.

Szulc, J., Gradzinski, M., Lewandowska, A., Heunisch, C., 2006. The Upper Triassic crenogenic limestones in Upper Silesia (southern Poland) and their paleoenvironmental context. In: Alonso-Zarza, A.M., Tanner, L.H. (Eds), Paleoenvironmental Record and Applications of Calcretes and Palustrine Carbonates. Geological Society of America, Special Paper 416, pp. 153-168. 
Tandon, S.K., Andrews, J.E., 2001. Lithofacies associations and stable isotopes of palustrine and calcrete carbonates: examples from an Indian Maastrichtian regolith. Sedimentology 48, 339-355.

Tullner, T., Cserny, T., 2003. New aspects of lake-level changes: Lake Balaton, Hungary. Acta Geologica Hungarica 46, 215-238.

Valdeolmillos Rodríguez, A., 2005. Registro paleoclimático y paleoambiental de los últimos 350.000 años en el Parque Nacional de Las Tablas de Daimiel (Ciudad Real). Ph.D. Thesis, Alcalá de Henares Madrid, Universidad de Alcalá, 308 pp.

Valero, B.L., 1993. Lacustrine deposition and related volcanism in a transtensional tectonic setting: Upper Stephanian-Lower Autunian in the Aragón-Béarn Basin, western Pyrenees (Spain-France). Sedimentary Geology 83, 133-160.

Vázquez-Urbez, M., Arenas, C., Pardo, G., 2002. Facies fluvio-lacustres de la Unidad superior de la Muela de Borja (Cuenca del Ebro): modelo sedimentario. Revista de la Sociedad Geológica de España 15, 41-54.

Verrecchia, E.P., 2007. Lacustrine and palustrine geochemical sediments. In: Nash, D.J., McLaren, S.J. (Eds), Geochemical Sediments and Landscapes. Blackwell Publishing, Oxford, pp. 298-329.

Wright, V.P., 1986. The role of fungal biomineralization in the formation of early Carboniferous soil fabrics. Sedimentology 33, 831-838.

Wright, V.P., 1990. Syngenetic formation of grainstones and pisolites from fenestral carbonates in peritidal settings: discussion. Journal of Sedimentary Petrology 60, $309-310$.

Wright, V.P., Alonso-Zarza, A.M., Sanz, M.E., Calvo, J.P., 1997. Diagenesis of Late Miocene micritic lacustrine carbonates, Madrid Basin, Spain. Sedimentary Geology 114, $81-95$.

Wright, V.P., Azeredo, A.C., 2006. How relevant is the role of macrophyte vegetation in controlling peritidal carbonate facies? Clues from the Jurassic of Portugal. Sedimentary Geology 186, 147-156.

Wright, V.P., Marriott, S.B., 1993. The sequence stratigraphy of fluvial depositional systems: the role of floodplain sediment storage. Sedimentary Geology 86, 203-210.

Wright, V.P., Platt, N.H., 1995. Seasonal wetland carbonate sequences and dynamic catenas: a reappraisal. Sedimentary Geology 99, 65-71.

Wright, V.P., Platt, N.H., Wimbledon, W., 1988. Biogenic laminar calcretes: evidence of calcified root mat horizons in palaeosols. Sedimentology 35, 603-620.

Wright, V.P., Sandler, A., 1994. A hydrogeological model for the early diagenesis of Late Triassic alluvial sediments. Journal of the Geological Society 151, 897-900. 